\title{
EFEK SAMPING KOSMETIK DAN PENANGANANYA BAGI KAUM PEREMPUAN
}

\author{
Lina Pangaribuan*) \\ Surel: lina.pangaribuan30@gmail.com
}

\begin{abstract}
Cosmetics is an important requirement role in the field of beauty for the beauty of the human body that is in need in appearance. Nowadays there are many cosmetic products circulating in the market with various brands and shapes also found dangerous materials in cosmetic products sold in the market. Dangerous substances are commonly found in whitening, anti-aging, and some makeup cosmetics. Some ingredients that have been banned by the Food and Drug Administration (BPOM) on cosmetic products include mercury, hydroquinone, retinoic acid, red dye, Rhodamine $B$. While this hazardous material can cause irritation, allergies, physical blockage, local or systemic poisoning even affect the network system and other important organs. So the side effects of cosmetics are now becoming increasing both in quality and quantity. Therefore special handling and underlying knowledge are needed to deal with all cosmetic issues. Knowledge of cosmetics can help in determining the cosmetics to be used. Consumers should be selective in choosing cosmetics products in order to avoid mistakes in choosing cosmetics so that the negative impact of cosmetic use can be avoided. Side effects of using this illegal cosmetic can be very harmful to the human body. Side effects resulting from this cosmetic can continuously result in the outbreak of cancer, heart failure. The chemicals contained in the cosmetics can exceed the standards used for cosmetics that can raise health risks. Unconsciously the condition is caused by carelessness of the consumer as a user, while doing unconscious daily activities, so that the chemical substances into the body.
\end{abstract}

Keywords: side effects, Cosmetics and women

\section{PENDAHULUAN}

eiring dengan berkembangnya
pengetahuan dan teknologi,
maka kebutuhan terhadap kecantikan terus berkembang, sejalan dengan kebutuhan untuk mempercantik diri pun kini menjadi prioritas utam $^{1}$ a kaum perempuan dalam menunjang penampilan seharihari. Kaum perempuan akan selalu berusaha untuk mengubah penampilan

*Dra. Lina Pangaribuan, M.Pd. Dosen Jurusan PKK FT UNIMED atau mempercantik diri dengan menggunakan kosmetika. Keinginan untuk mempercantik diri secara berlebihan, salah pengertian akan kegunaan kosmetik, menyebabkan kaum perempuan sering berbuat kesalahan dalam memilih dan menggunakan kosmetik tanpa memperhatikan kondisi kulit dan pengaruh lingkungan. Hasil yang didapatkan tidak membuat kulit menjadi sehat dan cantik, tetapi malah terjadi berbagai kelainan kulit yang disebabkan oleh penggunaan kosmetika tersebut. Gaya hidup yang 
kini terjadi pada masyarakat khususnya kaum perempuan baik di kota maupun di desa, membuat para produsen kosmetik berlomba-lomba mempromosikan produknya, selain melalui iklan, mereka tidak segansegan memangsa konsumennya dalam ketidak tahuan mereka, sehingga banyak kaum perempuan yang terjebak dalam dilemma ketidak mengertian mereka tentang konsmetika tersebut secaru menyeluruh.

Sejalan dengan itu, kemajuan bidang kesehatan juga ikut melesat dari waktu ke waktu, khususnya pada bidang Kosmetikologi, tidaklah menjadi sesuatu barang yang mewah bahkan kosmetik menjadi hal yang wajib bagi kaum perempuan. Kebutuhan akan mempercantik diri pun kini menjadi prioritas utama dalam menunjang penampilan seharihari, antara lain dengan mengubah penampilan atau mempercantik diri dengan menggunakan kosmetika.

Berdasarkan pengamatan sekilas, sekarang ini kaum perempuan cenderung memiliki masalah dengan kulit nya sendiri, terutama kulit wajah yaitu timbulnya hiperpigmentasi atau noda hitam pada wajah. Hiperpigmentasi timbul karena adanya berbagai sebab antara lain faktor usia, perawatan yang salah, paparan sinar matahari secara langsung, penggunaan alat kontrasepsi dan kesalahan penggunaan kosmetik. Adanya kecenderungan untuk mengkonsumsi kosmetika pemutih pada masyarakat membuat produsen kosmetika bersaing dalam memproduksi dan mempromosikan produk kosmetika pemutih. Tujuan dibuatnya makalah ini ialah untuk memberikan informasi kepada pembaca tentang suatu kosmetik, bagaimana kosmetik yang baik dan hal-hal apa saja yang perlu diperhatikan dalam penggunaan suatu kosmetik, sehingga kesalah dalam penggunaan kosmetik dapat dihindari lebih dini.

\section{KAJIAN TEORITIS}

Pada abad ke-19, pemakaian kosmetik mulai mendapat perhatian, yaitu selain untuk kecantikan juga untuk kesehatan. Menurut Tranggono sambil mengutip Jellinek dkk (1970) perkembangan ilmu kosmetik serta industrinya baru dimulai secara besarbesaran pada abad ke-20. Kosmetik berasal dari kata Yunani "kosmetikos" yang berarti ketrampilan menghias, mengatur. Defenisi kosmetik dalam Peraturan Kepala Badan Pengawas Obat dan Makanan RI No. HK.00.05.42.1018 adalah setiap bahan atau sediaan dimaksudkan untuk digunakan pada bagian luar tubuh manusia (epidermis, rambut, kuku, bibir, dan organ genital bagian luar) atau gigi dan mukosa mulut terutama untuk membersihkan, mewangikan, mengubah penampilan dan atau 
memperbaiki bau badan atau melindungi atau memelihara tubuh pada kondisi baik (BPOM RI, 2008).

Kosmetik saat ini telah menjadi kebutuhan manusia khususnya kaum perempuan yang tidak bisa dipandangan dengan sebelah mata lagi, semakin terasa bahwa kebutuhan terhadap kosmetik yang beraneka bentuk dengan ragam warna dan keunikan kemasan serta keunggulan dalam memberikan fungsi bagi konsumen menuntut industri kosmetik untuk semakin terpicu mengembangkan teknologi yang tidak saja mencakup peruntukkannya dari kosmetik itu sendiri namun juga kepraktisannya didalam penggunaannya. Penggunaan kosmetik harus disesuaikan dengan aturan pakainya, misalnya harus sesuai jenis kulit, warna kulit, iklim, cuaca, waktu penggunaan, umur, dan jumlah pemakaiannya sehingga tidak menimbulkan efek yang tidak diinginkan. Sebelum mempergunakan kosmetik, sangatlah penting untuk mengetahui lebih dulu apa yang dimaksud dengan kosmetik, manfaat dan pemakaian yang benar, oleh karena itu perlu penjelasan lebih detail mengenai kosmetik (Djajadisastra, 2005).

Menurut Peraturan Menteri Kesehatan RI No. 220 tahun 1976 "Kosmetik adalah bahan atau campuran bahan untuk digosokkan diletakkan, dituangkan, dipercikkan, atau disemprotkan pada, dimasukkan dalam, dipergunakan pada badan atau bagian badan manusia dengan maksud untuk membersihkan, memelihara, menambah daya tarik atau mengubah rupa dan tidak termasuk golongan obat." Uraian di atas menjelaskan bahwa yang dimaksud kosmetik adalah suatu campuran bahan yang digunakan pada tubuh bagian luar dengan berbagai cara untuk merawat dan mempercantik diri sehingga dapat menambah daya tarik dan menambah rasa percaya diri pemakaian dan tidak bersifat mengobati atau menyembuhkan suatu penyakit tertentu. Sekarang ini telah banyak produk kosmetik yang beredar di pasaran dengan berbagai macam merek dan bentuk.

Kosmetik yang beredar di pasaran sekarang ini dibuat dengan berbagai jenis bahan dasar dan cara pengolahannya. Menurut bahan yang digunakan dan cara pengolahannya, kosmetik dapat dibagi menjadi 2 golongan besar yaitu kosmet ik tradisional dan kosmet ik modern. Kosmetik yang beredar di Indonesia ada dua macam yaitu kosmetik tradisional dan kosmetik modern.

a. Kosmetik Tradisional; Kosmetik tradisional adalah kosmetik alamiah atau kosmetik asli yang dapat dibuat sendiri langsung dari bahan-bahan segar atau yang 
telah dikeringkan, buah-buahan dan tanam-tanaman disekitar kita.

b. Kosmetik

Modern;

Kosmetik modern adalah

kosmetik yang diproduksi secara pabrik (laboratorium), dimana telah dicampur dengan zat-zat kimia untuk mengawetkan kosmetik tersebut agar tahan lama, sehingga tidak cepat rusak.

\section{PEMBAHASAN}

\section{Dampak Kosmetik Terhadap Kulit}

Efek Kosmetik terhadap Kulit merupakan sasaran utama dalam menerima berbagai pengaruh dari penggunaan kosmetika. Ada dua efek atau pengaruh kosmetika terhadap kulit, yaitu efek positif dan efek negatif. Tentu saja yang diharapkan adalah efek positifnya, sedangkan efek negatifnya tidak diinginkan karena dapat menyebabkan kelainan-kelainan kulit (Tranggono, 1996). Pemakaian kosmetika yang sesuai dengan jenis kulit akan berdampak positif terhadap kulit sedangkan pemakaian kosmetikan yang tidak sesuai dengan jenis kulit akan berdampak negatif bagi kulit.

Usaha yang dapat dilakukan dalam menghindari efek samping dari pemakaian kosmetika tersebut diantaranya adalah mencoba terlebih dahulu jenis produk baru yang akan digunakan untuk melihat cocok tidaknya produk tersebut bagi kulit. Setiap pemakaian produk kosmetika diharapkan dapat berkhasiat sesuai dengan jenis produk yang kita gunakan, akan tetapi sering kali pemakaian produk kosmetika tersebut justru membawa petaka bagi pemakainya. Efek-efek negatif yang sering kali timbul dari pemakaian kosmetika yang salah adalah kelainan kulit berupa kemerahan, gatal, atau noda-noda hitam.

Ada empat faktor yang mempengaruhi efek kosmetika terhadap kulit, yaitu faktor manusia pemakainya, faktor lingkungan alam pemakai, faktor kosmetika dan gabungan dari ketiganya.

a. Faktor manusia: Perbedaan warna kulit dan jenis kulit dapat menyebabkan perbedaan reaksi kulit terhadap kosmetika, karena struktur dan jenis pigmen melaminnya berbeda.

b. Faktor iklim: Setiap iklim memberikan pengaruh tersendiri terhadap kulit, sehingga kosmetika untuk daerah tropis dan sub tropis seharusnya berbeda.

c. Faktor kosmetika: Kosmetika yang dibuat dengan bahan berkualitas rendah Atau bahan yang berbahaya bagi kulit dan 
cara pengolahannya yang kurang baik, dapat menimbulkan reaksi negatif atau kerusakan kulit seperti alergi atau iritasi kulit.

d. Faktor gabungan dari ketiganya: Apabila bahan yang digunakan kualitasnya kurang baik, cara pengolahannya kurang baik dan diformulasikan tidak sesuai dengan manusia dan lingkungan pemakai maka akan dapat menimbulkan kerusakan kulit, seperti timbulnya reaksi alergi, gatal-gatal, panas dan bahkan terjadi pengelupasan.

Kosmetika memiliki efek terhadap kulit yaitu efek negatif dan efek positif. Demikian juga untuk kosmetika pemutih yang mempunyai efek positif yaitu menjadikan kulit lebih cerah atau putih seperti yang diinginkan dan mempunyai efek negatif yang berbahaya karena dapat menyebabkan kerusakan kulit seperti kulit meradang atau terkelupas apabila penggunaannya kurang berhati-hati atau tidak sesuai dengan petunjuk penggunannya.

Produk pemutih kulit adalah salah satu jenis produk kosmetika yang mengandung bahan aktif yang dapat menekan atau menghambat pembentukan melanin atau menghilangkan melanin yang sudah terbentuk sehingga akan memberikan warna kulit yang lebih putih. Keinginan seseorang untuk bisa tampil cantik dan memiliki kulit yang putih bersih telah membuat seseorang bersikap konsumtif. Dampak positif yang dapat diperoleh dari pemakaian kosmetika pemutih diantaranya yaitu kulit menjadi putih bersih dan bersinar. Keterbatasan pengetahuan tentang berbagai produk kosmetika pemutih membuat mereka tidak tahu dampak negatif yang timbul jika tidak berhatihati. Kesalahan yang dilakukan dapat menyebabkan gangguan terhadap kesehatan kulit. Penggunaan kosmetik, khususnya pemutih secara berlebihan dapat membahayakan kesehatan kulit.

Kosmetika pemutih biasanya mengandung zat aktif pemutih seperti hidroquinon dan merkuri. Hidroquinon yang banyak dipakai sebagai penghambat pembentukan melamin yang dapat menyebabkan hiperpigmentasi, pada hal melamin berfungsi sebagai pelindung kulit dari sinar ultraviolet, sehingga terhindar dari resiko terkena kanker kulit. Apabila digunakan dalam jangka waktu yang lama dan di bawah sinar matahari secara langsung, hidroquinon dapat mengakibatkan noda hitam dan benjolan kekuningan pada kulit yang disebut sebagai okrosinosis yang sifatnya permanen sebagai akibat terhambatnya produksi melanin kulit yang berfungsi melindungi kulit dari sinarultraviolet. 
Pemakaian merkuri dalam krim pemutih meskipun dapat menjadikan kulit tampak putih mulus, lamakelamaan akan mengendap di dalam kulit. Pemakaian bertahun-tahun akan menyebabkan kulit biru kehitaman dan memicu timbulnya kanker. Kurangnya pengetahuan dan informasi yang bisa didapatkan oleh pengguna kosmetika pemutih dapat menyebabkan seseorang melakukan kesalahan. Pada mulanya adalah keinginan untuk membuat kulit menjadi putih dan cantik, tetapi hasil yang didapatkan malah sebaliknya. Tidak jarang pengguna kosmetik pemutih mengeluh karena kulitnya merah meradang setelah menggunakan kosmetika pemutih.

\section{Zat Kimia Yang Terkandung Dalam Kosmetik}

Berikut beberapa bahan berbahaya yang sering dijumpai pada kosmetik dan produk perawatan kulit lainnya. Bahan berikut adalah bahan sintetik yang sudah terbukti berbahaya bagi kesehatan menurut beberapa penelitian.

\section{a. Sodium Lauryl Sulfate (SLS) and Ammonium Lauryl Sulfate (ALS)}

Zat ini sering dikatakan berasal dari sari buah kelapa untuk menutupi racun alami yang terdapat di dalamnya. Zat ini sering digunakan untuk campuran shampoo, pasta gigi, sabun wajah, pembersih badan dan sabun mandi. SLS dan ALS dapat menyebabkan iritasi kulit yang hebat dan kedua zat ini dapat dengan mudah diserap ke dalam tubuh. Setelah terserap, endapan zat ini akan terdapat pada otak, jantung, paru paru dan hati yang akan menjadi masalah kesehatan jangka panjang. SLS dan ALS juga berpotensi menyebabkan katarak dan menganggu kesehatan mata.

\section{b. Bahan Pengawet Paraben}

Paraben digunakan terutama pada kosmetik, deodoran, dan beberapa produk perawatan kulit lainnya. Zat ini dapat menyebabkan kemerahan dan reaksi alergi pada kulit. Penelitian terakhir di Inggris menyebutkan bahwa ada hubungan antara penggunaan paraben dengan peningkatan kejadian kanker payudara pada perempuan. Disebutkan pula terdapat konsentrasi paraben yang sangat tinggi pada $90 \%$ kasus kanker payudara yang diteliti.

\section{c. Propylene Glycol}

Ditemukan pada beberapa produk kecantikan, kosmetik dan pembersih wajah. Zat ini dapat menyebabkan kemerahan pada kulit dan dermatitis kontak. Studi terakhir juga menunjukan bahwa zat ini dapat merusak ginjal dan hati.

p-ISSN: 1693-1157, e-ISSN: 2527-9041 


\section{d. Isopropyl Alcohol}

Alkohol digunakan sebagai pelarut pada beberapa produk perawatan kulit. Zat ini dapat menyebabkan iritasi kulit dan merusak lapisan asam kulit sehingga bakteri dapat tumbuh dengan subur. Disamping itu, alkohol juga dapat menyebabkan penuaan dini.

\section{e. DEA (Diethanolamine), TEA} (Triethanolamine) and MEA (Monoethanolamine)

Bahan ini jamak ditemukan pada kosmetik dan produk perawatan kulit. Bahan bahan berbahaya ini dapat menyebabkan reaksi alergi dan penggunaan jangka panjang diduga dapat meningkatkan resiko terjadinya kanker ginjal dan hati.

\section{f. Aluminium}

Aluminium sering digunakan pada produk penghilang bau badan. Aluminium diduga berhubungan dengan penyakit pikun atau Alzheimer's.

g. Minyak Mineral

Minyak mineral dibuat dari turunan minyak bumi dan sering digunakan sebagai bahan dasar membuat krim tubuh dan kosmetik. Baby oil dibuat dengan $100 \%$ minyak mineral. Minyak ini akan melapisi kulit seperti mantel sehingga pengeluaran toksin dari kulit menjadi terganggu. Hal ini akan menyebabkan terjadinya jerawat dan keluhan kulit lainnya.
h.Polyethylene Glycol (PEG). Bahan ini digunakan untuk mengentalkan produk kosmetik. PEG akan menganggu kelembaban alami kulit sehingga menyebabkan terjadinya penuaan dini dan kulit menjadi rentan terhadap bakteri.

\section{Cara Memilih Kosmetik Yang Baik}

Sebelum membeli kosmetika sebaiknya memperhatikan hal-hal sebagai berikut:

a. Kenali jenis kulit dengan tepat

Jenis kulit setiap orang tidak sama, oleh karena itu penting untuk mengetahui jenis kulit sebelum memutuskan untuk membeli kosmetik yang cocok. Untuk memastikan jenis kulit seseorang, kulit harus dibersihkan lebih dahulu dan pemeriksaan harus dilakukan di bawah cahaya yang terang bila perlu menggunakan kaca pembesar agar tekstur kulit, besarnya pori-pori, aliran darah, pigmentasi, dan kelainan lain yang terdapat pada permukaan kulit dapat terlihat. Analisis kulit sangat penting dilakukan untuk menentukan kelainan atau masalah kulit yang timbul sehingga perlakukan yang tepat dapat diberikan untuk memperbaikinya (BPOM RI, 2007). 
b. Memilih produk kosmetik yang mempunyai nomor registrasi dari Departemen Kesehatan

Suatu produk kosmetik yang tidak memiliki nomor regr istrasi, kemungkinan memiliki kandungan zatzat yang tidak diizinkan pemakaiannya atau memiliki kadar yang melebihi ketentuan, sehingga dapat menimbulkan efek samping yang berbahaya. Hal yang perlu diperhatikan tersebut adalah berkaitan dengan kandungan hidroquinon dan merkuri yang terdapat pada produk kosmetik (BPOM RI, 2007).

c. Hati-hati dengan produk yang sangat cepat memberikan hasil.

Suatu produk kosmetik yang memberikan hasil yang sangat cepat (misalnya produk pemutih) tidak menutup kemungkinan produk tersebut mengandung zat yang melebihi kadar atau standar yang sudah ditetapkan oleh Depatemen Kesehatan dan penggunaannya harus di bawah pengawasan dokter (BPOM RI, 2007).

d. Membeli kosmetik secukupnya pada tahap awal

Setiap pertama kali menggunakan produk, tidak bisa diketahui apakah produk tersebut cocok digunakan atau tidak, oleh karena itu perlu mencobanya terlebih dahulu dalam jumlah sedikit (BPOM RI, 2007). e. Perhatikan keterangan-keterangan yang tercantum pada label atau kemasan.

Perlu diperhatikan informasi yang tertera pada kemasan mengenai unsur bahan yang digunakan, tanggal kadaluarsa serta nomor registrasinya, karena tidak semua produsen mencantumkan atau mendaftarkan produknya ke Badan Pengawasan Obat dan Makanan, sehingga tidak terjamin keamanannya (BPOM RI, 2007).

\section{KESIMPULAN}

Kosmetika merupakan suatu bahan yang dapat digunakan untuk mempercantik atau merawat diri. Secara definitif kosmetika diartikan sebagai suatu ilmu yang mempelajari kandungan bahan dan manfaat yang dihasilkan oleh pemakaian bahan tersebut terhadap penampilan dan kecantikan seseorang kosmetika adalah suatu campuran bahan yang digunakan pada tubuh bagian luar dengan berbagai cara untuk merawat dan mempercantik diri sehingga dapat menambah daya tarik dan menambah rasa percaya diri pemakaian dan tidak bersifat mengobati atau menyembuhkan suatu penyakit tertentu. Kosmetika yang beredar dipasaran Indonesia ada tiga macam, yaitu kosmetika tradisional, kosmetika modern. Efek Kosmetik terhadap Kulit merupakan sasaran utama dalam 
menerima berbagai pengaruh dari penggunaan kosmetika. Ada dua efek atau pengaruh kosmetika terhadap kulit, yaitu efek positif dan efek negative. Pehatikan dan maknai lebih lanjut dan baik, terhadap daftar kandungan yang terdapat pada label setiap produk kosmetik. Lihatlah apakah jenis jenis zat diatas terkandung di dalamnya, bila anda masih kurang yakin, anda bisa mencarinya di internet tentang bahayanya bahan tersebut. Jangan pernah dibodohi oleh kata kata 'natural' dan 'organic' pada kemasan produk. Memang produk tersebut mengandung satu atau dua bahan organik, tetapi kandungan bahan berbahayanya bisa berkali lipat jumlahnya.

\section{DAFTAR PUSTAKA}

Tranggono, Retno dkk. 2007. Buku Pegangan Ilmu Pengetahuan Kosmetik. Jakarta: Gramedia Pustaka Utama.

Wasitaatmadja, M.S,. 1997. Penuntun Ilmu Kosmetik Medik. UI-Press. Jakarta.
Fitryane, Rannie. 2011. Kiat Cantik \& Menarik. Bandung: Yrama Widya

Sari, Dian Maya. 2012. Perawatan Body Spa, Manicure dan Pedicure, Bleaching Tangan dan Kaki, Mahendi Tangan. Universitas Negeri Medan.

Suciati. 2010. Massage. Diakses pada 10 Februari 2016 dari http://file.upi.edu/Direktori/FPTK/JUR .PEND. KESEJAHTERAAN_KEL UARGA/197501282001122SUCIATI/Massage.pdf

Ilahi, Hikmah. 2010. Panduan Tata Rias Kecantikan Wajah Terkini. Jakarta: Flashbooks

Kicantik, 2014. Cara Make Up Karakter Zombie. Diakses pada tanggal 16 September 2015 dari http://kicantik.com/cara-makeup-karakter-zombiel.Diposting oleh kicantik pada 07:35, 18maret-14 